Review

\title{
New Insights into the Activities of D-Chiro-Inositol: A Narrative Review
}

\author{
Riccardo Gambioli ${ }^{1}$, Mario Montanino Oliva ${ }^{2,3}$ (-), Maurizio Nordio ${ }^{2,4}$, Alfonsina Chiefari ${ }^{5}$, Giulia Puliani ${ }^{5}$ \\ and Vittorio Unfer ${ }^{2,6, *}$
}

check for updates

Citation: Gambioli, R.; Montanino Oliva, M.; Nordio, M.; Chiefari, A.; Puliani, G.; Unfer, V. New Insights into the Activities of D-Chiro-Inositol: A Narrative Review. Biomedicines 2021, 9, 1378. https://doi.org/ 10.3390/biomedicines 9101378

Academic Editor: Jason Collier

Received: 14 September 2021

Accepted: 30 September 2021

Published: 2 October 2021

Publisher's Note: MDPI stays neutral with regard to jurisdictional claims in published maps and institutional affiliations.

Copyright: (C) 2021 by the authors Licensee MDPI, Basel, Switzerland. This article is an open access article distributed under the terms and conditions of the Creative Commons Attribution (CC BY) license (https:// creativecommons.org/licenses/by/ $4.0 /)$.
R\&D Department, Lo.Li. Pharma, 00156 Rome, Italy; gambioli.riccardo@gmail.com

2 The Experts Group on Inositol in Basic and Clinical Research (EGOI), 00161 Rome, Italy; mario.montanino@artemisia.it (M.M.O.); maurizionordio1@gmail.com (M.N.)

3 Department of Obstetrics and Gynecology, Santo Spirito Hospital, 00193 Rome, Italy

4 Department of Experimental Medicine, Sapienza University, 00185 Rome, Italy

5 Oncological Endocrinology Unit, IRCCS Regina Elena National Cancer Institute, 00144 Rome, Italy; alfonsina.chiefari@ifo.gov.it (A.C.); giulia.puliani@ifo.gov.it (G.P.)

6 System Biology Group Lab, 00161 Rome, Italy

* Correspondence: vunfer@gmail.com

\begin{abstract}
D-chiro-inositol (DCI) is a natural compound detectable in cell membranes, which is highly conserved as a biological signaling molecule. In mammals, its function is primarily characterized in the intracellular transduction cascade of insulin. In particular, insulin signal promotes the release of pivotal DCI-containing molecules. In fact, impaired release of DCI is a common feature of insulinresistant tissues, and insulin-sensitizing pharmaceuticals induce higher concentrations of free DCI. Moreover, it also plays important roles in several other processes. DCI is involved in the regulation of steroidogenesis, due to its regulatory effects on steroidogenic enzymes, including $17 \alpha$-hydroxylase, $3 \beta$-hydroxysteroid dehydrogenase, and aromatase. Such regulation of various enzymes indicates a mechanism by which the body regulates different processes via a single molecule, depending on its concentration. DCI also reduces the expression of integrin $\beta 3$, which is an adhesion molecule involved in embryo implantation and cellular phenomena such as survival, stemness, and invasiveness. In addition, DCI seems to have important anti-inflammatory activities, like its 3-O-methyl-ether, called pinitol. In vitro evidence demonstrates that treatment with both compounds induces a reduction in pro-inflammatory factors-such as Nf- $\mathrm{kB}$ - and cytokines-such as TNF- $\alpha$. DCI then plays important roles in several fundamental processes in physiology. Therefore, research on such molecule is of primary importance.
\end{abstract}

Keywords: inositol; D-chiro-inositol; insulin; steroidogenesis; integrins; inflammation

\section{Introduction}

D-chiro-inositol (DCI) is the second most represented isomer of the inositol family in mammals [1]. Inositols are cyclo-hexane polyols, differing from each other depending on the orientation of the six hydroxyl groups. DCI plays pivotal roles in several physiological processes and can be either absorbed through the diet or derived from its most represented relative, myo-inositol (MI) [2]. In fact, a NADH/NADPH-dependent epimerase enzyme specifically converts MI to DCI at physiological $\mathrm{pH}$, either on the membranes or in the cytosol [3]. Both isomers are involved in membrane plasticity, participating in signal transduction by modulating the response to endocrinological stimuli [1]. Ultimately, both MI and DCI are catabolized by Myo-Inositol Oxygenase (MIOX), producing D-glucuronate, that eventually joins the pentose-phosphates cycle as D-xylulose-5-phosphate [4].

Throughout the whole body, each tissue or cellular type displays a peculiar ratio of MI to DCI. Actually, high MI/DCI ratios are present in almost every tissue, except for those deputed to storage, which display higher contents of DCI at the expense of MI [5]. 
Both MI and DCI exist in the intracellular space in one of their phosphate forms, either as inositol-phosphates (IP), free molecules in water solution, or as phosphatidylinositolphosphate (PIP), hydrophilic components of the phospholipid bilayer [2]. Particularly, PIP may take part in a structure generally referred to as glycosylphosphatidylinositol anchor (GPI anchor). Indeed, through the addition of a glycan, generally composed of an amino-sugar and several saccharides, and a phosphoethanolamine linker, PIP connects to the C-terminal of a protein, resulting in proteins that are GPI-anchored to cell membranes. Noteworthy, GPI-anchored proteins represent a mechanism of primary importance, as defects in GPI anchor biosynthesis are lethal during embryo development in mammals [6].

Under unstimulated conditions, MI and DCI mainly exist as phosphatidylinositol-4,5bisphosphate (PIP2), either unconjugated or associated with glycans. Following extracellular signals, PIP2 can undergo several modifications [7]. On the one hand, a phosphorylation of unconjugated inositol phosphates by Phosphatidylinositol-3-Kinase (PI3K) can produce phosphatidylinositol-3,4,5-trisphosphate (PIP3). On the other hand, Phospholipase C (PLC) can catalyze the release of inositol from cell membranes, producing inositol-1,4,5trisphosphates (IP3) from unconjugated PIP2 [8]. Noteworthy, not only IP3 can be released from the membranes, but also inositol phosphoglycans (IPGs).

In all the processes involving inositol signaling, a difference between MI and DCI is not always clear. Nevertheless, MI content is lower in storage tissues as fat, muscle, and liver, while higher contents are found the other tissues [2]. This evidence, the available data on the mechanisms involving specifically DCI, and the data from clinical trials allow us to develop theories about molecular differences. This paper aims at evaluating those data, focusing on the actual and plausible roles played by DCI.

\section{Insulin}

Insulin is a well-known hormone produced by pancreatic $\beta$-cells, whose principal role is to promote cellular absorption of glucose. Insulin receptor is a tyrosine kinase transmembrane receptor existing as a dimer. Once the ligand binds, the receptor self-phosphorylates in the cytoplasmatic portion, allowing recognition by its interactors. Among these, Insulin Receptor Substrate 1 (IRS-1) and 2 (IRS-2) were demonstrated to interact with the inositol signaling pathway [8]. Particularly, both IRS-1 and IRS-2 interact with the p85 subunit of PI3K, whose role is to regulate the activity of the catalytic subunit p110, especially the isoforms $\mathrm{p} 110 \alpha$ and $\mathrm{p} 110 \beta$. Activated IRSs promote the phosphorylation of $\mathrm{p} 85$, reducing its inhibition of the coupled p110, and thus the insulin stimulus results in enhanced PI3K activity [9]. Interestingly, in physiology, the two p110 isoforms seem to have different downstream effects, especially on the proto-oncogenic protein Akt [10].

Therefore, the insulin stimulus promotes the formation of PIP3 via PI3K, leading to downstream signal transduction. On the other hand, via direct interaction [11], insulin induces an about three-fold higher activity of PLC- $\gamma 1$, thus promoting the release of IP3 from the membranes to the cytosol. However, this generates a slight and transient depletion in PIP2, temporarily removing substrates for other processes such as the formation of GPI anchors [12].

In the insulin pathway, DCI is considered a key molecule in the signaling cascade (Figure 1). In fact, DCI-based IPGs (DCI-IPGs) participate as signaling molecules in signal transduction by the insulin receptor. Particularly, the action of insulin promotes the phospholipase-mediated release of a DCI-IPG mediator. This DCI-IPG is a pseudodisaccharide composed of galactosamine and pinitol, which is the 3-O-methyl ether of DCI [13]. In addition to the cytoplasm, extracellular environments like serum show the presence of DCI-IPG, whose role as an insulin mediator and an insulin sensitizer is widely described in the literature [7,14-18]. Noteworthy, DCI-IPGs in the bloodstream derives from phospholipase-mediated cleavage and release of DCI-IPGs from the outer part of the membranes. To trigger this mechanism, phospholipase is expressed as a GPI-anchored protein on the external layer of cell membranes, where it allows the extracellular release of DCI-IPGs $[6,19]$. To date, conflicting evidence exists on the phosphodiesterase that catalyzes 
the release of DCI-IPGs from the membrane. Sleight et al. found that a heterodimer of G-proteins is involved in the release of IPGs, also highlighting its colocalization with PLC $\beta$ and PLC $\delta$ [20]. Despite this, there is lack of evidence on the existence of an IPG-specific PLC in mammals, while it has been detected in bacteria [21]. Another hypothesis concerns the activity of Phospholipase D (PLD), which catalyzes the cleavage of IPGs between phosphate and inositol, rather than between phosphate and glycerol, as PLC does [21]. This cleavage seems to be of primary importance in insulin downstream effects, specifically, in glucose uptake [22]. Further evidence from Bonilla et al. highlighted that bovine-derived PLD specifically cleaves DCI-IPGs, while PLC purified from bacteria cannot [23]. Moreover, protein-free IPGs usually undergo palmitoyl-acylation on carbon 2, which prevents the cleavage of PLC but not that of PLD [21]. Nevertheless, due to the existence of a bovine PLC that hydrolyzes IPGs, the possibility of a similar lipase cannot be ruled out in humans, making the issue still debated [6].

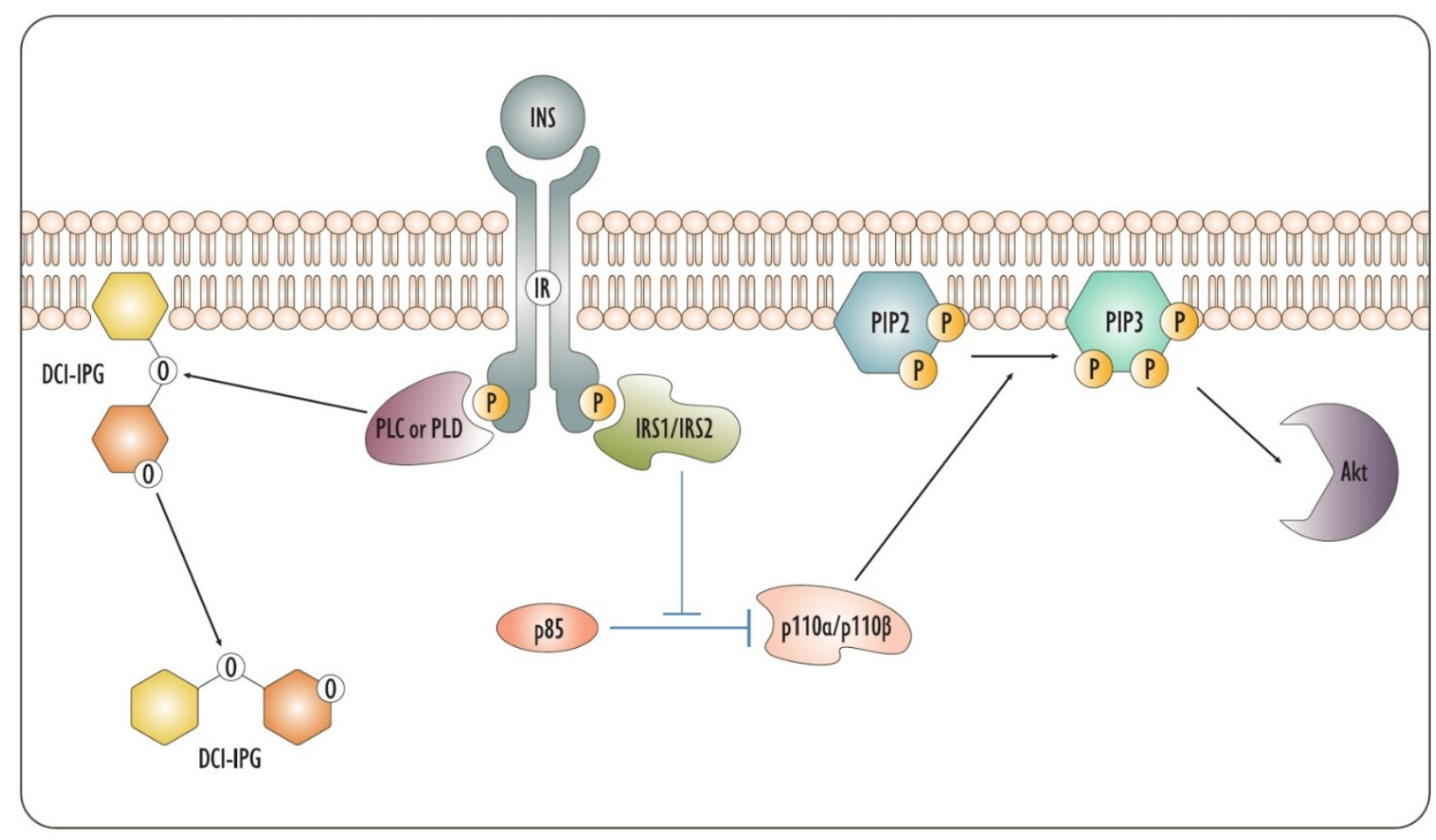

Figure 1. The figure depicts the insulin pathways based on inositol. On the one hand, IRS1 and IRS2 remove the inhibition of p85 on p110, thus promoting the conversion of PIP2 to PIP3, leading to the activation of downstream effectors such as Akt. On the other hand, an enzyme of the phosphodiesterase family, whose identity is, to date, debated and which could be PLC or PLD, cleaves DCI-IPGs from the membrane, allowing downstream transmission of the signal. DCI-IPG: DCI-based inositol phosphoglycans; INS: Insulin; IRS1/IRS2: Insulin Receptor Substrate 1/Insulin Receptor Substrate 2; PIP2: phosphatidylinositol-4,5-bisphosphate; PIP3: phosphatidylinositol-3,4,5-trisphosphate; PLC: Phospholipase C; PLD: Phospholipase D.

Larner et al. proposed that DCI-IPGs derive from the hydrolysis of phospholipids in the membrane, from IPGs linked to proteins, or from both [13]. DCI-IPGs are also characterized as promoters of Pyruvate Dehydrogenase activity via the activation of Pyruvate Dehydrogenase Phosphatase [13]. In addition, DCI-IPGs also activate Protein Phosphatase 2C (PP2C) [24], which represents an important effector that further allows PIP3 production, as PP2C directly activates PI3K [25]. These two pathways in turn lead to insulin sensitization and promote energetic metabolism in the cells.

In pancreatic environment, DCI-IPGs stimulate insulin secretion from pancreatic $\beta$ cells. In fact, high glucose levels in the bloodstream induce a systemic higher activity of PLC, promoting the release of DCI-IPGs [26]. Eventually, DCI-IPGs induce the secretion of 
insulin via the closure of ATP-sensitive potassium channels. In fact, DCI-IPG treatment fails to potentiate insulin secretion following the chemically induced closure of ATP-sensitive potassium channels. Noteworthy, PP2C is strictly required for the closure of ATP-sensitive potassium channels stimulated by DCI-IPGs and, thus, for insulin release from pancreatic $\beta$-cells [27]. DCI also prevents palmitate-induced insulin resistance in pancreatic $\alpha$-cells, whose role is to secrete glucagon, which would promote the release of glucose in the bloodstream [28]. Thus, impaired DCI signal may also alter glucagon homeostasis, thus impairing the secretion of glucose. Therefore, DCI-IPGs play a pivotal role in maintaining glucose homeostasis in human organisms. Further confirmation of these facts derives from an in vitro study on the effect of insulin and glucose on inositol uptake. Indeed, the insulin stimulus promotes the upregulation of Sodium/Myo-Inositol Transporter 2 (SMIT2), which transports both MI and DCI, while DCI transport is competitively inhibited by small quantities of glucose [29].

As suggested by several clinical trials, the release of DCI-IPGs strongly relates to insulin sensitivity $[17,18]$. In fact, impaired release of DCI-IPGs from cell membranes characterizes insulin-resistant subjects, and DCI administration improves insulin sensitivity, reducing insulin levels [30,31]. Moreover, patients affected by diabetes mellitus show enhanced urinary excretion of DCI and impaired levels of circulating DCI, demonstrating the pivotal role of such molecule [32].

Other than in the response to insulin, DCI is involved in the maturation of adipocytes. In particular, DCI induces the activation of IRS without upregulating the expression of the insulin substrate. On the contrary, insulin induces both the expression and the phosphorylation of IRS, resulting in an unchanged ratio of activated IRS to total IRS [33]. As a consequence, DCI partially mimics the effect of insulin, augmenting the relative activation of IRS to a greater extent. In fact, given the ability of DCI to improve IRS phosphorylation grade without upregulating the gene, the stimulated cell will better respond to additional insulin stimulus. Therefore, insulin resistance and impaired release of DCI further reduce insulin sensitivity, in a pathological, positive feedback.

Additional demonstrations on the importance of DCI in insulin physiology derive from the mechanisms of action of insulin-sensitizing pharmaceuticals. In particular, metformin and pioglitazone, two well-known insulin sensitizers, exert their roles through mechanisms involving the improvement of DCI-IPG release [17,34]. Therefore, the improved signal of insulin mediated by DCI-IPGs represents an important part of these pharmaceuticals' mechanisms. However, insulin does not transduce only via DCI, and in a similar way DCI do not participate only in insulin signaling.

\section{Steroidogenesis}

Other than in insulin signaling, DCI proved to be pivotal in several other endocrine processes. Intriguingly, DCI also participates in the pathways of gonadotropins. Particularly, as it emerges from a clinical point of view, DCI may act as a Luteinizing Hormone (LH) sensitizer, reducing endogenous LH synthesis and improving LH signaling [35-37]. This is probably due to the involvement of inositols and inositol-phosphates in LH signaling pathway. However, the LH receptor is a complex protein involving not only inositol but also several other downstream mediators and effectors [38].

Another evidence of the importance of DCI in hormonal regulation derives from its inhibition of the expression of aromatase [39,40]. Aromatase is an enzyme that catalyzes the aromatization of the A-ring of androgens to produce estrogens and it is the only enzyme that synthesizes estrogens. On the other hand, estradiol [41,42] and Follicle-Stimulating Hormone (FSH) $[43,44]$ induce aromatase expression. Both estrogen and gonadotropin transduce through inositol phosphates [45-48]. Being DCI an inhibitor of aromatase expression, it is likely that estradiol and FSH block DCI signals in favor of MI, leading to the expression of aromatase. On the contrary, LH downregulates aromatase [43,49], as insulin does [40,50]. Remarkably, insulin-dependent inhibition of aromatase expression is mediated by DCI-IPGs [40]. Therefore, in the menstrual cycle, FSH induces the expression 
of the LH receptor and aromatase before ovulation. The latter is further supported by positive feedback from newly produced estrogens. A following peak of LH signal strongly inhibits aromatase [49,51], as confirmed by the decrease in the output of estrogens following the LH stimulus [52]. Based on the affinity with insulin effects, this LH-induced inhibition of aromatase expression is probably allowed by DCI-containing mediators (Figure 2).

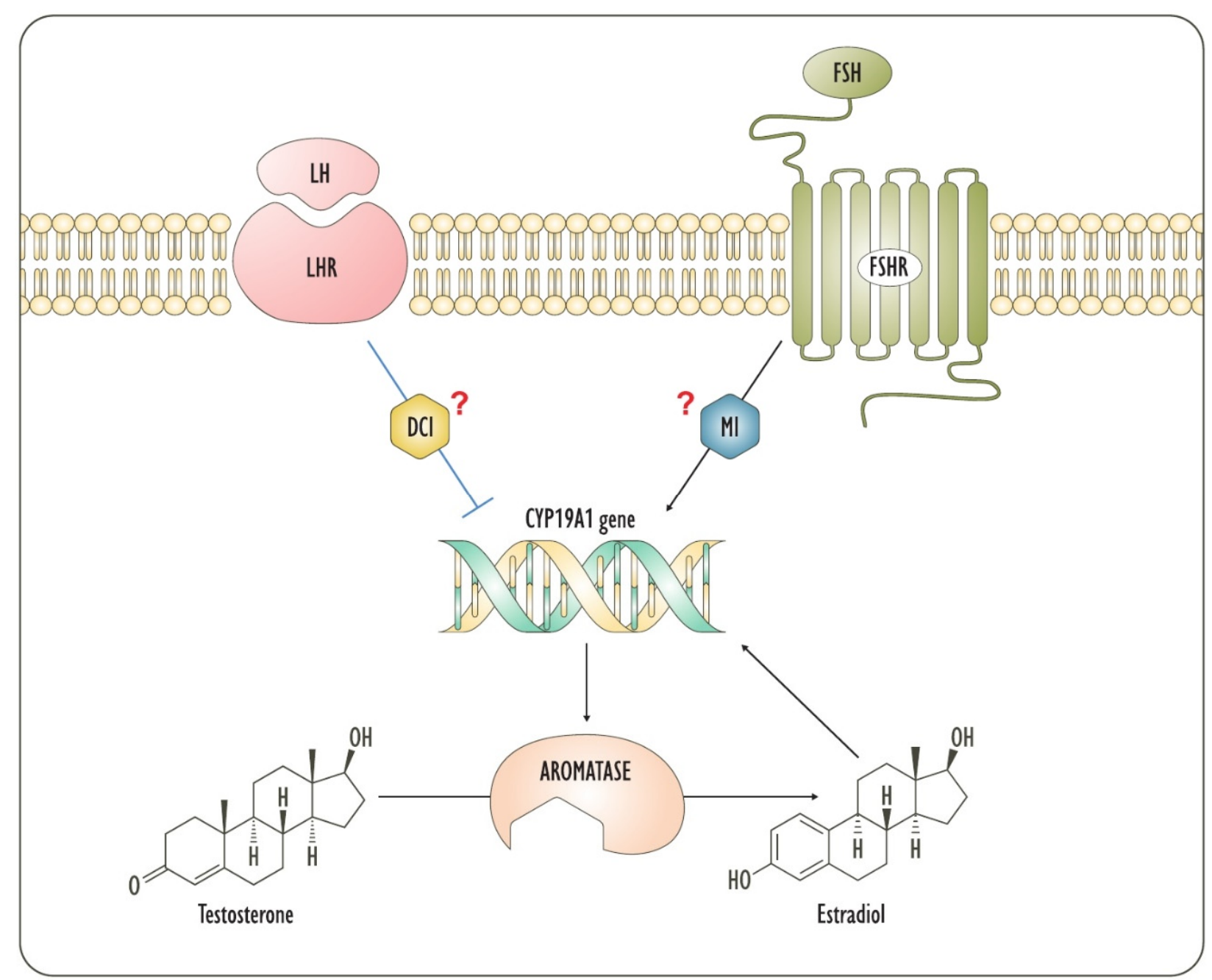

Figure 2. The figure depicts the regulation by LH and FSH of aromatase expression. Gonadotropins are involved in ovarian steroidogenesis through their intracellular mediators, which are strongly supposed to be inositols. Actually, LH signal involves principally theca cells, while FSH primarily acts on granulosa. DCI: D-chiro-inositol; FSH: Follicle-Stimulating Hormone; FSHR: Follicle-Stimulating Hormone Receptor; LH: Luteinizing Hormone; LHR: Luteinizing Hormone Receptor; MI: Myo-inositol.

In accordance with the interpretation of DCI as a promoter of higher androgen concentrations, in men DCI is detectable in higher content than in women, and males also display a lower MI/DCI ratio in the urine [53]. Though DCI seems to promote androgens synthesis, the mechanism involves the inhibition of aromatase, and so DCI actually inhibits androgen catabolism rather than promoting their biosynthesis. Intriguingly, low DCI levels do not trigger androgen accumulation. In fact, the LH receptor has a low affinity for proteins involved in the inositol pathway [38], and thus only extremely high levels of $\mathrm{LH}$, as it occurs in men or in women during ovulation, inhibit aromatase [43]. On the contrary, the proteins associated with the insulin receptor have high affinity for PI3K [8]; therefore, even small DCI quantities allow sensitization to insulin. Therefore, insulin and LH likely share inositol signals, even if to different extents. Thus, distinct stimuli promote 
the release of different DCI quantities, which mediate different activities depending on the final DCI concentration.

Altered concentrations of DCI are involved in ovarian deregulated pathways in insulinresistant subjects, who display a higher insulin content. In fact, the ovary never displays the insulin resistance phenomenon, therefore suffering from overburdening insulin stimuli in insulin-resistant patients [54]. As a consequence of this high insulin signaling, the membranes release high DCI-IPGs quantities, which result in ovarian testosterone accumulation [55].

Intriguingly, both DCI and MI promote the activity of $3 \beta$-hydroxysteroid dehydrogenase ( $3 \beta$-HSD), which oxidizes the -OH group on the A-ring of progestogens and androgens. This is a regulation of primary importance during embryo development, particularly in the cytotrophoblast. In the latter, in fact, Nestler et al. demonstrated that both MI-IPGs and DCI-IPGs promote the production of progesterone in a concentration-dependent manner through a positive regulation on $3 \beta$-HSD [40]. Likewise, via PI3K, insulin improves the activity of $17 \alpha$-hydroxylase, also known as 17,20 lyase, which catalyzes the production of androgens from progestogens [56]. In fact, diabetic patients with high insulin levels and impaired DCI signals show reduced conversion of progestogens into androgens [57]. This likely suggests that DCI induces the activity or the expression of $17 \alpha$-hydroxylase, leading to a high conversion rate of progestogens to androgens. Nevertheless, DCI is also a transcriptional inhibitor of aromatase; thus, the insulin stimulus would result in an accumulation of androstenedione and testosterone at the expense of progestogens, dehydroepiandrosterone, androstenediol, and estrogens. Indeed, this imply that DCI may act as a promoter of androgens anabolism, also blocking their catabolism and thus avoiding the risks of anabolic steroids (Figure 3).

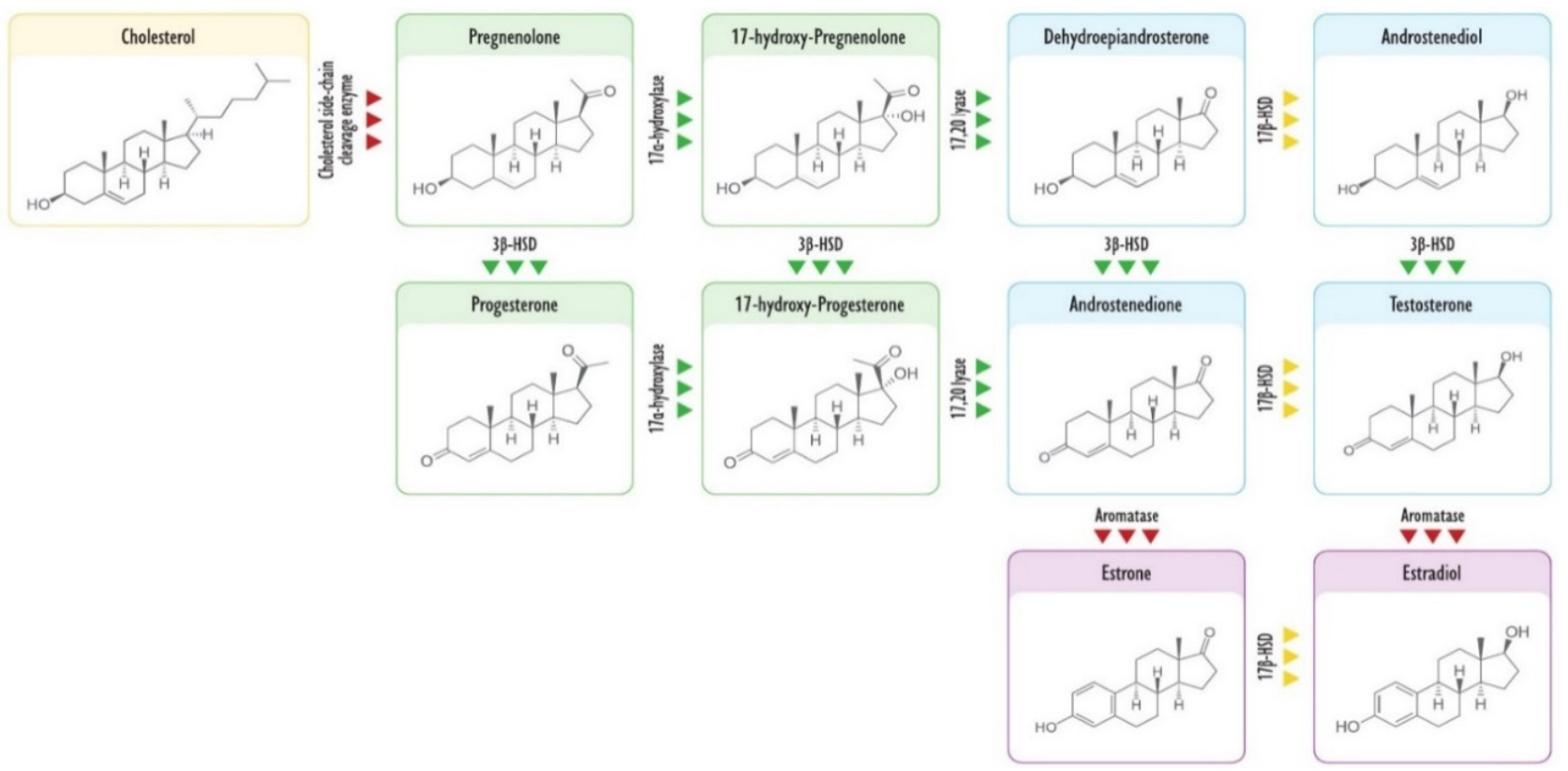

Figure 3. The figure reports the principal products of steroidogenesis and the enzymes involved. Yellow background depicts cholesterol; green background depicts progestogens; blue background depicts androgens; pink background depicts estrogens; green triangles indicate enzymes upregulated by DCI; yellow triangles indicate enzymes whose possible regulation by DCI is still unknown to date; red triangles indicate enzymes downregulated by DCI.

In physiological contexts, the insulin-dependent fine regulation of these enzymes would allow correct steroidogenesis to occur. However, in pathological clinical pictures such as diabetes and insulin resistance, an altered DCI signal would impair steroidogenesis, in addition to euglycemia. Particularly, women suffering from Poly-Cystic Ovary Syndrome (PCOS) usually display insulin resistance [5] and show increased DCI content in the 
ovary, coupled with a lack of DCI in non-germinal tissues [58]. Moreover, PCOS women display increased presence of steroidogenic enzymes in thecal and granulosa cells, including $17 \alpha$-hydroxylase [59]. Therefore, treating PCOS women with insulin-sensitizing agents such as metformin reduces $17 \alpha$-hydroxylase activity, allowing physiological steroidogenesis [60]. Concomitantly, the improved signals of insulin, that would lead to physiological signals via DCI, would also allow the recovery of the physiological expression and activity of aromatase and $3 \beta-\mathrm{HSD}$. Therefore, DCI is nowadays considered an efficient insulinsensitizing agent. However, at the ovarian level, high DCI quantities would exacerbate the impaired steroidogenesis, increasing the conversion of progestogens into androgens and impairing androgens catabolism. In fact, its administration in high content for a prolonged time seems to induce a PCO-like phenotype [61].

Intriguingly, the enhanced activity of $17 \alpha$-hydroxylase in insulin-resistant women may represent a compensatory mechanism. In fact, in the case of altered insulin signaling, progesterone acts on the liver increasing blood glucose levels [62]. Therefore, the regulation by DCI of $17 \alpha$-hydroxylase activity may derive from an adaptive mechanism to prevent the onset of a severer hyperglycemia. In this manner, the body would mitigate the effects of impaired insulin, inhibiting progesterone-induced hyperglycemia and thus avoiding more critical situations. However, the regulation by DCI of these enzymes leads to hyperandrogenism in pathological contexts involving impaired insulin signal [2].

\section{Integrins}

Other than the effects of DCI upon aromatase expression, Sacchi et al. [39] found further evidence of the effects of such a molecule on gene expression. Based on promising results from Lin et al. [63] involving treatment with pinitol, they demonstrated that DCI treatment also reduces the expression of integrin $\beta 3$ in vitro. Integrins are transmembrane adhesion proteins, existing as heterodimers. Specifically, each mature integrin is composed of a specific $\alpha$-chain and a specific $\beta$-chain. Interestingly, integrins not only provide adhesion to cells but also participate in cellular signaling pathways. In fact, liganded integrins transduce a signal of survival in epithelial cells through Focal Adhesion Kinase (FAK) and the proto-oncogene tyrosine protein kinase Src (c-Src). On the contrary, unliganded integrins do not provide a survival signal, inducing death in those cells that lose anchorage [64].

Physiologically, the $\beta 3$ chain is detectable both in platelets, associated with the integrin $\alpha \mathrm{IIb}$ or with the integrin $\alpha \mathrm{v}$, and in epithelial tissues, where it is commonly associated with the integrin $\alpha \mathrm{v}$. The ligands of $\alpha \mathrm{v} \beta 3$ include vitronectin, osteopontin, fibronectin, fibrinogen, and thyroxine [65]. In pathological contexts, $\beta 3$ signal and mechanical anchorage is involved in several etiological processes, including cancer metastasis.

A low expression of integrin $\beta 3$ is found in fat tissue, which is characterized by a high DCI content. However, $\beta 3$ expression in fat tissue is related to body fat mass and insulin resistance. Thus, high body fat mass and insulin resistance induce high $\beta 3$ expression [66]. Noteworthy, insulin-resistant tissues are characterized by a reduced DCI content [2]. Therefore, the fat mass of an insulin-resistant subject would display reduced levels of DCI, which in turn allow higher levels of $\beta 3$ integrin. This could represent a cellular compensatory mechanism to restore insulin signal. In fact, $\beta 3$ integrins interact with the insulin receptor, supporting its signal and likely amplifying the downstream cascade [64]. In this way, the correlation found in vitro by Sacchi et al. [39] between DCI and $\beta 3$ integrins likely represents a physiological mechanisms of insulin sensitization.

Another physiological process involving integrin $\beta 3$ as a factor of primary importance is embryo implantation. In fact, in uterine endometrium, integrin $\beta 3$ is expressed from the early secretory phase to the menses and throughout the entire pregnancy [67]. On the other hand, also osteopontin [68] and vitronectin [69] are expressed during the same periods. Interestingly, also the embryo itself shows the expression of both integrin $\beta 3$ and osteopontin [70]. Specifically, both osteopontin and integrin $\beta 3$ are expressed on the surface of the trophoblast and at the implantation site [70]. Moreover, integrin $\beta 3$ is necessary for 
the correct embryo implantation, as its inhibition leads to troublesome pregnancies or no pregnancy at all [71]. Intriguingly, the inhibition of integrin $\beta 3$ leads to a higher relative abundance of natural killer cells and to a higher level of proinflammatory cytokines such as Interferon- $\gamma$, Tumor Necrosis Factor- $\alpha$, and Interleukin-17 [71]. This is probably an eventual effect of failed implantation rather than a direct effect of a lack in integrin $\beta 3$, as the body promotes the elimination of the trophoblast.

An indirect confirmation of the need for integrin $\beta 3$ in physiological pregnancy derives from the analysis of endometrium samples from infertile women. Endometrium samples from women suffering from unexplained infertility [72] or recurrent pregnancy loss [73] were examined for their integrin $\beta 3$ content. Researchers found that the endometria of both these populations of women are characterized by a low content of integrin $\beta 3$. Further evidence is presented by the findings of Lessey et al. [74], who described the expression of integrin $\beta 3$ in endometrium samples from healthy women and from women suffering from endometriosis, either fertile or infertile. They found that the normal expression of integrin $\beta 3$ characterizes the endometrium of fertile women, regardless of their endometriosis condition, while infertile patients display reduced integrin $\beta 3$ expression. This suggests that integrin $\beta 3$ directly relates to fertility rather than to fertility-impairing pathologies.

Intriguingly, estrogens and progestogens seem to play important roles in the regulation of integrin $\beta 3$. In particular, researchers found that estradiol reduces the expression of integrin $\beta 3$, while the counteracting action of progesterone induces its expression in endometrial cells [75]. In this manner, progesterone improves the endometrial receptivity of embryos during the uterine secretory phase, preparing the milieu for implantation. Interestingly, progesterone induces the expression of integrin $\beta 3$ via the induction of the expression of Heparin-Binding Epidermal-growth-factor-like-Growth-Factor (HBEGF) [76]. Noteworthy, HBEGF activity is mediated by PI3K, and thus the presence of PIP3 assists the eventual effects of progesterone on integrin $\beta 3$ [77]. In this context, the diametrically opposite actions of insulin and progesterone emerge once again, as a high insulin signal reduces integrin $\beta 3$ expression, while a high progesterone signal induces it.

\section{Inflammation and Cancer}

The inhibitory effects of pinitol and DCI upon integrin expression were further investigated in cancer, as these adhesion molecules play pivotal roles in cancer etiopathogenesis and progression. In fact, integrin $\beta 3$ is considered a pro-tumorigenic integrin, as it relates to the metastatic and invasive processes, and its downregulation suppresses these phenomena [78]. Noteworthy, integrins can combine with membrane receptors with tyrosine kinase activity. The combination of an integrin and a receptor massively amplifies the signaling of both. In particular, integrin $\beta 3$ showed combinatory activity with receptors of primary importance, including those for insulin, insulin-like growth factor 1 (IGF-1), Epidermal Growth Factor (EGF), and Vascular Endothelial Growth Factor (VEGF) [64]. Another important receptor that concomitantly supports and is supported by integrin $\beta 3$ is Tyrosine Kinase receptor B (Trk-B) [79]. Trk-B is a membrane surface receptor that binds Brain-Derived Neurotrophic Factor (BDNF). This receptor coupled with integrin $\beta 3$ promotes epithelial-mesenchymal transition and resistance to anoikis, i.e., detachmentinduced death [80-82].

Another notable process involving integrin $\beta 3$ in cancer is stemness maintenance and, thus, avoidance of differentiation. In fact, researchers found that integrin $\beta 3$ is strictly required for the onset of some cancer types, such as acute myeloid leukemia, while its knockdown induces the differentiation of cancer cells [83]. This finding, in accordance with the high expression of integrin $\beta 3$ in healthy and cancerous stem cells, underlines that integrin $\beta 3$ may represent a hypothetical marker of stemness. Furthermore, integrin $\beta 3$ counteracts the effects of chemotherapeutic inhibitors of the EGF receptor through stemness induction in cancer cells, allowing the establishment of resistance to these pharmaceuticals [84]. Of interest, the mechanisms underlying integrin- $\beta 3$-mediated 
resistance to inhibitors of the EGF receptor seem to involve the activation of Nuclear Factor kappa-light-chain-enhancer of activated B cells (Nf-kB) [64].

Intriguingly, pinitol displayed anti-metastatic properties via the inhibition of the expression of integrin $\beta 3$ and the reduction of the activity of c-Src and Nf- $\mathrm{kB}$ [63]. Particularly, pinitol seems to inhibit Nf- $\mathrm{kB}$-induced genes, which include pro-inflammatory genes, such as cyclooxygenase-2 (COX2); genes related to proliferation, such as c-myc and cyclin D1; genes supporting survival, such as Bcl-2 and Bcl-xL; genes promoters of angiogenesis, such as VEGF; genes related to invasiveness, such as matrix metalloprotease-9 (MMP-9) [85]. Additionally, pinitol seems to reduce the synthesis of cytokines with pro-inflammatory activity, such as Tumor necrosis factor- $\alpha$ (TNF- $\alpha$ ), and angiogenetic activity, such as Interleukin8 [86]. It also modulates the immune response of T-helper cells, demonstrating a possible adjuvant effect in complex clinical pictures characterized by inflammation $[87,88]$.

All these results concern pinitol, which is an ether of DCI, but most of these findings have not been confirmed for DCI yet. Nevertheless, DCI already proved to have similar and, in some cases, even better effects. In fact, firstly, DCI was shown to induce a greater reduction of the expression of integrin $\beta 3$ than pinitol $[39,63]$. Secondly, DCI modulates the redox state and inflammation in adipocytes, downregulating TNF- $\alpha$ and Interleukin- 6 , which are modulator of the inflammatory response [89]. Moreover, DCI-IPGs demonstrated the ability to reduce the secretion of leptin, a pro-inflammatory factor, from adipocytes, even if to a lesser extent than MI-based IPGs [90].

Further evidence of the ability of DCI to prevent the onset of environments favoring malignancies derives from its effects on oxidative stress. In particular, DCI inhibits the expression of NADPH oxidase 4 (NOX4) and induces the activity Nuclear-factor-erythroid2-Related Factor 2 (NRF2) [91]. NOX4 is a mitochondrial enzyme that produces free oxygen radicals, which increase oxidative stress and the inflammatory response of the cell [92]. Of interest, NRF2 is a key regulator in the homeostasis of oxidative stress and metabolism, which impacts on several other signaling cascades [93]. Therefore, in recent years, researchers focused their efforts on the search for pharmaceuticals that could enhance the effectiveness of NRF2 [93,94]. In this regard, DCI may likely represent a safe adjuvant treatment, reducing the inflammatory status and removing the integrin $\beta 3$ stimulus to survival. Despite the encouraging in vitro evidence regarding both DCI $[95,96]$ and pinitol $[63,85,97-99]$ (Table 1), we should emphasize the lack of in vivo studies to date. If this evidence will be confirmed by appropriate in vivo data, cancer adjuvant treatment will represent an interesting field of application for a molecule of such potential.

Table 1. The table summarizes the in vitro evidence existing on the molecular regulation by DCI and Pinitol of genes relevant in cancer progression. c-Src: Proto-oncogene tyrosine protein kinase Src; COX2: cyclooxygenase-2; DCI: D-chiro-inositol; MMP-9: matrix metalloprotease-9; Nf-kB: nuclear factor kappa-light-chain-enhancer of activated B cells; NOX4: NADPH oxidase 4; NRF2: nuclearfactor-erythroid-2-related Factor 2; TNF- $\alpha$ : tumor necrosis factor- $\alpha$; VEGF: vascular endothelial growth factor.

\begin{tabular}{|c|c|c|c|c|}
\hline & Upregulated Genes & Downregulated Genes & & Downregulated Genes \\
\hline \multirow{11}{*}{ DCI } & NRF-2 & Integrin $\beta 3$ & & Integrin $\beta 3$ \\
\hline & & $T N F-\alpha$ & & $T N F-\alpha$ \\
\hline & & $I L-6$ & & $I L-8$ \\
\hline & & Leptin & & $N F-\kappa B$ \\
\hline & & NOX4 & & $c-S r c$ \\
\hline & & & Pinitol & $c-m y c$ \\
\hline & & & & COX-2 \\
\hline & & & & Bcl-2 \\
\hline & & & & $B c l-x L$ \\
\hline & & & & $V E G F$ \\
\hline & & & & $M M P-9$ \\
\hline
\end{tabular}




\title{
6. Conclusions and Perspectives
}

In recent years, DCI has been widely used in clinical practice and investigated in clinical research. However, not all its physiological and therapeutical properties have been discovered yet, and further evidence is steadily emerging. Initially characterized as an insulin sensitizer and an insulin mimetic, today it is known that DCI plays pivotal roles also in the regulation of steroidogenesis and in other important processes, such as cell-to-cell adhesion and inflammation. Therefore, DCI is nowadays increasingly prescribed in clinical practice to treat a wide variety of diseases. In the future, research on the activity of DCI will undercover additional therapeutical properties of this natural and safe molecule, also gathering data on the molecular mechanisms underlying its therapeutic potential.

Author Contributions: Conceptualization, R.G., A.C., G.P. and V.U.; writing-original draft preparation, R.G., A.C. and G.P.; writing—review and editing, M.M.O. and M.N.; supervision, V.U.; project administration, M.M.O., M.N. and V.U. All authors have read and agreed to the published version of the manuscript.

Funding: The present work was not funded.

Institutional Review Board Statement: Not applicable.

Informed Consent Statement: Not applicable.

Data Availability Statement: Not applicable.

Acknowledgments: The authors would like to thank Monica Cannavò for the graphical support during the creation of the artwork.

Conflicts of Interest: Riccardo Gambioli and Vittorio Unfer are employed at Lo.Li. Pharma srl, Rome, Italy. The other authors report no conflict of interest.

\begin{abstract}
Abbreviations

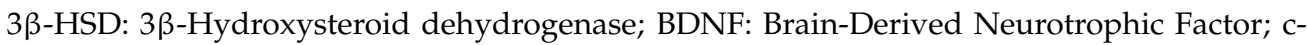
Src: Proto-oncogene tyrosine protein kinase Src; COX2: cyclooxygenase-2; DCI: D-chiro-inositol; DCI-IPGs: DCI-based IPGs; EGF: Epidermal Growth Factor; FAK: Focal Adhesion Kinase; FSH: Follicle-Stimulating Hormone; GPI-anchor: glycosylphosphatidylinositol anchor; HBEGF: HeparinBinding Epidermal-growth-factor-like-Growth-Factor; IGF-1: insulin-like growth factor 1; IP: inositol phosphates; IPGs: inositol phospho-glycans; IP3: inositol-1,4,5-trisphosphates; IRS-1: Insulin Receptor Substrate 1; IRS-2: Insulin Receptor Substrate 2; LH: Luteinizing Hormone; MMP-9: matrix metalloprotease-9; MI: myo-inositol; MIOX: Myo-Inositol Oxygenase; Nf-kB: Nuclear factor kappa-light-chain-enhancer of activated B cells; NOX4: NADPH oxidase 4; NRF2: Nuclear-factorerythroid-2-Related Factor 2; PCOS: Poly-Cystic Ovary Syndrome; PI3K: Phosphatidylinositol-3Kinase; PIP: phosphatidylinositol phosphate; PIP2: phosphatidylinositol-4,5 bisphosphate; PIP3: phosphatidylinositol-3,4,5 trisphosphate; PLC: Phospholipase C; PLD: Phospholipase D; PP2C: Protein Phosphatase 2C; SMIT2: Sodium/Myo-Inositol Transporter 2; TNF- $\alpha$ : Tumor necrosis factor- $\alpha$; Trk-B: Tyrosine Kinase receptor B; VEGF: Vascular Endothelial Growth Factor.
\end{abstract}

\section{References}

1. Bizzarri, M.; Fuso, A.; Dinicola, S.; Cucina, A.; Bevilacqua, A. Pharmacodynamics and pharmacokinetics of inositol(s) in health and disease. Expert Opin. Drug Metab. Toxicol. 2016, 12, 1181-1196. [CrossRef]

2. Gambioli, R.; Forte, G.; Aragona, C.; Bevilacqua, A.; Bizzarri, M.; Unfer, V. The use of D-chiro-Inositol in clinical practice. Eur. Rev. Med. Pharmacol. Sci. 2021, 25, 438-446. [PubMed]

3. Sun, T.-H.; Heimark, D.; Nguygen, T.; Nadler, J.L.; Larner, J. Both myo-inositol to chiro-inositol epimerase activities and chiroinositol to myo-inositol ratios are decreased in tissues of GK type 2 diabetic rats compared to Wistar controls. Biochem. Biophys. Res. Commun. 2002, 293, 1092-1098. [CrossRef]

4. Arner, R.J.; Prabhu, K.S.; Thompson, J.T.; Hildenbrandt, G.R.; Liken, A.D.; Reddy, C.C. myo-Inositol oxygenase: Molecular cloning and expression of a unique enzyme that oxidizes myo-inositol and d-chiro-inositol. Biochem. J. 2001, 360, 313-320. [CrossRef] [PubMed] 
5. Dinicola, S.; Chiu, T.T.Y.; Unfer, V.; Carlomagno, G.; Bizzarri, M. The rationale of the myo-inositol and D-chiro-inositol combined treatment for polycystic ovary syndrome. J. Clin. Pharmacol. 2014, 54, 1079-1092. [CrossRef]

6. Paulick, M.G.; Bertozzi, C.R. The Glycosylphosphatidylinositol Anchor: A Complex Membrane-Anchoring Structure for Proteins. Biochemistry 2008, 47, 6991-7000. [CrossRef]

7. Gambioli, R.; Forte, G.; Buzzaccarini, G.; Unfer, V.; Laganà, A. Myo-Inositol as a Key Supporter of Fertility and Physiological Gestation. Pharmaceuticals 2021, 14, 504. [CrossRef]

8. Goel, M.; Azev, V.N.; D'Alarcao, M. The biological activity of structurally defined inositol glycans. Futur. Med. Chem. 2009, 1, 95-118. [CrossRef]

9. Leroy, C.; Ramos, P.; Cornille, K.; Bonenfant, D.; Fritsch, C.; Voshol, H.; Bentires-Alj, M. Activation of IGF1R/p110ß/AKT/mTOR confers resistance to $\alpha$-specific PI3K inhibition. Breast Cancer Res. 2016, 18, 1-13. [CrossRef]

10. Matheny, R.W.; Adamo, M.L. PI3K p110 $\alpha$ and p110 $\beta$ have differential effects on Akt activation and protection against oxidative stress-induced apoptosis in myoblasts. Cell Death Differ. 2009, 17, 677-688. [CrossRef]

11. Kayali, A.G.; Eichhorn, J.; Haruta, T.; Morris, A.J.; Nelson, J.G.; Vollenweider, P.; Olefsky, J.M.; Webster, N.J.G. Association of the Insulin Receptor with Phospholipase C- $\gamma$ (PLC $\gamma)$ in 3T3-L1 Adipocytes Suggests a Role for PLC $\gamma$ in Metabolic Signaling by Insulin. J. Biol. Chem. 1998, 273, 13808-13818. [CrossRef]

12. Eichhorn, J.; Kayali, A.G.; Austin, D.A.; Webster, N.J. Insulin Activates Phospholipase C- $\gamma 1$ via a PI-3 Kinase Dependent Mechanism in 3T3-L1 Adipocytes. Biochem. Biophys. Res. Commun. 2001, 282, 615-620. [CrossRef]

13. Larner, J.; Brautigan, D.L.; Thorner, M.O. D-Chiro-Inositol Glycans in Insulin Signaling and Insulin Resistance. Mol. Med. 2010, 16, 543-552. [CrossRef]

14. Monastra, G.; Vazquez-Levin, M.; Espinola, M.S.B.; Bilotta, G.; Laganà, A.S.; Unfer, V. D-chiro-inositol, an aromatase downmodulator, increases androgens and reduces estrogens in male volunteers: A pilot study. Basic. Clin. Androl. 2021, $31,1-17$. [CrossRef]

15. Celentano, C.; Matarrelli, B.; Pavone, G.; Vitacolonna, E.; Mattei, P.A.; Berghella, V.; Liberati, M. The influence of different inositol stereoisomers supplementation in pregnancy on maternal gestational diabetes mellitus and fetal outcomes in high-risk patients: A randomized controlled trial. J. Matern. Neonatal Med. 2018, 33, 743-751. [CrossRef]

16. Nestler, J.E.; Jakubowicz, D.J.; Reamer, P.; Gunn, R.D.; Allan, G. Ovulatory and Metabolic Effects of d-Chiro-Inositol in the Polycystic Ovary Syndrome. N. Engl. J. Med. 1999, 340, 1314-1320. [CrossRef] [PubMed]

17. Baillargeon, J.-P.; Iuorno, M.J.; Jakubowicz, D.J.; Apridonidze, T.; He, N.; Nestler, J.E. Metformin Therapy Increases InsulinStimulated Release ofd-Chiro-Inositol-Containing Inositolphosphoglycan Mediator in Women with Polycystic Ovary Syndrome. J. Clin. Endocrinol. Metab. 2004, 89, 242-249. [CrossRef] [PubMed]

18. Cheang, K.I.; Baillargeon, J.-P.; Essah, P.A.; Ostlund, R.E.; Apridonize, T.; Islam, L.; Nestler, J.E. Insulin-stimulated release of d-chiro-inositol-containing inositolphosphoglycan mediator correlates with insulin sensitivity in women with polycystic ovary syndrome. Metabolism 2008, 57, 1390-1397. [CrossRef] [PubMed]

19. Romero, G.; Gamez, G.; Huang, L.C.; Lilley, K.; Luttrell, L. Anti-inositolglycan antibodies selectively block some of the actions of insulin in intact BC3H1 cells. Proc. Natl. Acad. Sci. USA 1990, 87, 1476-1480. [CrossRef] [PubMed]

20. Sleight, S.; Wilson, B.; Heimark, D.; Larner, J. Gq/11 is involved in insulin-stimulated inositol phosphoglycan putative mediator generation in rat liver membranes: Co-localization of $\mathrm{Gq} / 11$ with the insulin receptor in membrane vesicles. Biochem. Biophys. Res. Commun. 2002, 295, 561-569. [CrossRef]

21. López-Gambero, A.J.; Sanjuan, C.; Serrano-Castro, P.J.; Suárez, J.; De Fonseca, F.R. The Biomedical Uses of Inositols: A Nutraceutical Approach to Metabolic Dysfunction in Aging and Neurodegenerative Diseases. Biomedicines 2020, 8, 295. [CrossRef] [PubMed]

22. Kristiansen, S.; Richter, E.A. GLUT4-containing vesicles are released from membranes by phospholipase D cleavage of a GPI anchor. Am. J. Physiol. Metab. 2002, 283, E374-E382. [CrossRef] [PubMed]

23. Bonilla, J.B.; Cid, M.B.; Contreras, F.-X.; Goñi, F.M.; Martín-Lomas, M. Phospholipase Cleavage ofD- andL-chiroGlycosylphosphoinositides Asymmetrically Incorporated into Liposomal Membranes. Chem.-A Eur. J. 2006, 12, $1513-1528$. [CrossRef]

24. Brautigan, D.L.; Brown, M.; Grindrod, S.; Chinigo, G.; Kruszewski, A.; Lukasik, S.M.; Bushweller, J.H.; Horal, M.; Keller, S.; Tamura, S.; et al. Allosteric Activation of Protein Phosphatase 2C byd-chiro-Inositol-Galactosamine, a Putative Mediator Mimetic of Insulin Actiont. Biochemistry 2005, 44, 11067-11073. [CrossRef]

25. Yoshizaki, T.; Maegawa, H.; Egawa, K.; Ugi, S.; Nishio, Y.; Imamura, T.; Kobayashi, T.; Tamura, S.; Olefsky, J.M.; Kashiwagi, A. Protein Phosphatase-2C $\alpha$ as a Positive Regulator of Insulin Sensitivity through Direct Activation of Phosphatidylinositol 3-Kinase in 3T3-L1 Adipocytes. J. Biol. Chem. 2004, 279, 22715-22726. [CrossRef]

26. Zawalich, W.S.; Zawalich, K.C. Regulation of insulin secretion by phospholipase C. Am. J. Physiol. Metab. 1996, 271, E409-E416. [CrossRef]

27. Lazarenko, R.; Geisler, J.; Bayliss, D.; Larner, J.; Li, C. D-chiro-inositol glycan stimulates insulin secretion in pancreatic $\beta$ cells. Mol. Cell. Endocrinol. 2014, 387, 1-7. [CrossRef] [PubMed]

28. Filippello, A.; Scamporrino, A.; Di Mauro, S.; Malaguarnera, R.; Di Pino, A.; Scicali, R.; Purrello, F.; Piro, S. Direct Effects of D-Chiro-Inositol on Insulin Signaling and Glucagon Secretion of Pancreatic Alpha Cells. Biomolecules 2020, 10, 1404. [CrossRef] 
29. Lin, X.; Ma, L.; Fitzgerald, R.L.; Ostlund, R.E. Human sodium/inositol cotransporter 2 (SMIT2) transports inositols but not glucose in L6 cells. Arch. Biochem. Biophys. 2009, 481, 197-201. [CrossRef]

30. Baillargeon, J.-P.; Diamanti-Kandarakis, E.; Ostlund, R.E.; Apridonidze, T.; Iuorno, M.J.; Nestler, J.E. Altered D-Chiro-Inositol Urinary Clearance in Women with Polycystic Ovary Syndrome. Diabetes Care 2006, 29, 300-305. [CrossRef]

31. Baillargeon, J.-P.; Iuorno, M.J.; Apridonidze, T.; Nestler, J.E. Uncoupling Between Insulin and Release of a d-Chiro-InositolContaining Inositolphosphoglycan Mediator of Insulin Action in Obese Women with Polycystic Ovary Syndrome. Metab. Syndr. Relat. Disord. 2010, 8, 127-136. [CrossRef] [PubMed]

32. Ostlund, R.E.; McGill, J.B.; Herskowitz, I.; Kipnis, D.M.; Santiago, J.V.; Sherman, W.R. D-chiro-inositol metabolism in diabetes mellitus. Proc. Natl. Acad. Sci. USA 1993, 90, 9988-9992. [CrossRef] [PubMed]

33. Montt-Guevara, M.M.; Finiguerra, M.; Marzi, I.; Fidecicchi, T.; Ferrari, A.; Genazzani, A.D.; Simoncini, T. D-Chiro-Inositol Regulates Insulin Signaling in Human Adipocytes. Front. Endocrinol. 2021, 12, 283. [CrossRef]

34. Gupta, A.; Jakubowicz, D.; Nestler, J.E. Pioglitazone Therapy Increases Insulin-Stimulated Release of d-Chiro-Inositol-Containing Inositolphosphoglycan Mediator in Women with Polycystic Ovary Syndrome. Metab. Syndr. Relat. Disord. 2016, 14, 391-396. [CrossRef]

35. Genazzani, A.D.; Santagni, S.; Rattighieri, E.; Chierchia, E.; Despini, G.; Marini, G.; Prati, A.; Simoncini, T. Modulatory role of D-chiro-inositol (DCI) on LH and insulin secretion in obese PCOS patients. Gynecol. Endocrinol. 2014, 30, 438-443. [CrossRef]

36. Laganà, A.S.; Barbaro, L.; Pizzo, A. Evaluation of ovarian function and metabolic factors in women affected by polycystic ovary syndrome after treatment with d-Chiro-Inositol. Arch. Gynecol. Obstet. 2014, 291, 1181-1186. [CrossRef]

37. Nordio, M.; Basciani, S.; Camajani, E. The 40:1 myo-inositol/D-chiro-inositol plasma ratio is able to restore ovulation in PCOS patients: Comparison with other ratios. Eur. Rev. Med. Pharmacol. Sci. 2019, 23, 5512-5521.

38. Casarini, L.; Santi, D.; Brigante, G.; Simoni, M. Two Hormones for One Receptor: Evolution, Biochemistry, Actions, and Pathophysiology of LH and hCG. Endocr. Rev. 2018, 39, 549-592. [CrossRef] [PubMed]

39. Sacchi, S.; Marinaro, F.; Tondelli, D.; Lui, J.; Xella, S.; Marsella, T.; Tagliasacchi, D.; Argento, C.; Tirelli, A.; Giulini, S.; et al. Modulation of gonadotrophin induced steroidogenic enzymes in granulosa cells by d-chiroinositol. Reprod. Biol. Endocrinol. 2016, 14, 1-8. [CrossRef]

40. Nestler, J.E.; Romero, G.; Huang, L.C.; Zhang, C.; Larner, J. Insulin Mediators Are the Signal Transduction System Responsible for Insulin's Actions on Human Placental Steroidogenesis*. Endocrinology 1991, 129, 2951-2956. [CrossRef] [PubMed]

41. Hoffmann, R.; Niiyama, S.; Huth, A.; Kissling, S.; Happle, R. $17 \alpha$-estradiol induces aromatase activity in intact human anagen hair follicles ex vivo. Exp. Dermatol. 2002, 11, 376-380. [CrossRef] [PubMed]

42. Cisternas, C.; Zapata, L.E.C.; Arevalo, M.-A.; Garcia-Segura, L.; Cambiasso, M.J. Regulation of aromatase expression in the anterior amygdala of the developing mouse brain depends on ER $\beta$ and sex chromosome complement. Sci. Rep. 2017, 7, 1-13. [CrossRef] [PubMed]

43. Fitzpatrick, S.L.; Richards, J.S. Regulation of Cytochrome P450 Aromatase Messenger Ribonucleic Acid and Activity by Steroids and Gonadotropins in Rat Granulosa Cells *. Endocrinology 1991, 129, 1452-1462. [CrossRef] [PubMed]

44. Haltia, U.-M.; Pihlajoki, M.; Andersson, N.; Mäkinen, L.; Tapper, J.; Cervera, A.; Horlings, H.M.; Turpeinen, U.; Anttonen, M.; Bützow, R.; et al. Functional Profiling of FSH and Estradiol in Ovarian Granulosa Cell Tumors. J. Endocr. Soc. 2020, 4, bvaa034. [CrossRef]

45. Marino, M.; Distefano, E.; Trentalance, A.; Smith, C. Estradiol-induced IP3 mediates the estrogen receptor activity expressed in human cells. Mol. Cell. Endocrinol. 2001, 182, 19-26. [CrossRef]

46. Szatkowski, C.; Parys, J.B.; Ouadid-Ahidouch, H.; Matifat, F. Inositol 1,4,5-trisphosphate-induced Ca ${ }^{2+}$ signalling is involved in estradiol-induced breast cancer epithelial cell growth. Mol. Cancer 2010, 9, 1-13. [CrossRef]

47. Chaurasiya, S.; Wu, W.; Strom, A.M.; Warner, M.; Gustafsson, J.-Å. Estrogen receptor $\beta$ regulates AKT activity through upregulation of INPP4B and inhibits migration of prostate cancer cell line PC-3. Proc. Natl. Acad. Sci. USA 2020, 117, 26347-26355. [CrossRef] [PubMed]

48. Maruyama, N.O.; Lucas, T.F.G.; Porto, C.S.; Abdalla, F.M.F. Estrogen receptor ESR1 regulates the phospholipase C-inositol phosphate signaling in the hippocampus from rats in proestrous and estrous phases. Steroids 2013, 78, 8-14. [CrossRef]

49. Stocco, C. Aromatase expression in the ovary: Hormonal and molecular regulation. Steroids 2008, 73, 473-487. [CrossRef]

50. Fuhrmeister, I.P.; Branchini, G.; Pimentel, A.M.; Ferreira, G.D.; Capp, E.; Brum, I.S.; Corleta, H.V.E. Human Granulosa Cells: Insulin and Insulin-Like Growth Factor-1 Receptors and Aromatase Expression Modulation by Metformin. Gynecol. Obstet. Investig. 2014, 77, 156-162. [CrossRef]

51. Fitzpatrick, S.L.; Carlone, D.L.; Robker, R.; Richards, J.S. Expression of aromatase in the ovary: Down-regulation of mRNA by the ovulatory luteinizing hormone surge. Steroids 1997, 62, 197-206. [CrossRef]

52. McNatty, K.P.; Makris, A.; Osathanondh, R.; Ryan, K.J. Effects of luteinizing hormone on steroidogenesis by thecal tissue from human ovarian follicles in vitro. Steroids 1980, 36, 53-63. [CrossRef]

53. Campbell, W.W.; Ostlund, J.R.E.; Joseph, L.J.; Farrell, P.A.; Evans, W.J. Relationships of Plasma C-Peptide and Gender to the Urinary Excretion of Inositols in Older People. Horm. Metab. Res. 2001, 33, 44-51. [CrossRef] [PubMed]

54. Carlomagno, G.; Unfer, V.; Roseff, S. The D-chiro-inositol paradox in the ovary. Fertil. Steril. 2011, 95, 2515-2516. [CrossRef] [PubMed] 
55. Nestler, J.E.; Jakubowicz, D.J.; De Vargas, A.F.; Brik, C.; Quintero, N.; Medina, F. Insulin Stimulates Testosterone Biosynthesis by Human Thecal Cells from Women with Polycystic Ovary Syndrome by Activating Its Own Receptor and Using Inositolglycan Mediators as the Signal Transduction System 1. J. Clin. Endocrinol. Metab. 1998, 83, 2001-2005. [CrossRef]

56. Munir, I.; Yen, H.-W.; Geller, D.H.; Torbati, D.; Bierden, R.M.; Weitsman, S.R.; Agarwal, S.K.; Magoffin, D.A. Insulin Augmentation of $17 \alpha$-Hydroxylase Activity Is Mediated by Phosphatidyl Inositol 3-Kinase but not Extracellular Signal-Regulated Kinase-1/2 in Human Ovarian Theca Cells. Endocrinol. 2004, 145, 175-183. [CrossRef]

57. Ueshiba, H.; Shimizu, Y.; Hiroi, N.; Yakushiji, F.; Shimojo, M.; Tsuboi, K.; Miyachi, Y. Decreased steroidogenic enzyme 17,20-lyase and increased 17-hydroxylase activities in type 2 diabetes mellitus. Eur. J. Endocrinol. 2002, 146, 375-380. [CrossRef]

58. Heimark, D.; McAllister, J.; Larner, J. Decreased myo-inositol to chiro-inositol (M/C) ratios and increased M/C epimerase activity in PCOS theca cells demonstrate increased insulin sensitivity compared to controls. Endocr. J. 2014, 61, 111-117. [CrossRef]

59. Jakimiuk, A.J.; Weitsman, S.R.; Navab, A.; Magoffin, D.A. Luteinizing Hormone Receptor, Steroidogenesis Acute Regulatory Protein, and Steroidogenic Enzyme Messenger Ribonucleic Acids Are Overexpressed in Thecal and Granulosa Cells from Polycystic Ovaries 1. J. Clin. Endocrinol. Metab. 2001, 86, 1318-1323. [CrossRef]

60. Nestler, J.E.; Jakubowicz, D.J. Decreases in Ovarian Cytochrome P450c17 $\alpha$ Activity and Serum Free Testosterone after Reduction of Insulin Secretion in Polycystic Ovary Syndrome. N. Engl. J. Med. 1996, 335, 617-623. [CrossRef]

61. Bevilacqua, A.; Dragotto, J.; Lucarelli, M.; Di Emidio, G.; Monastra, G.; Tatone, C. High Doses of D-Chiro-Inositol Alone Induce a PCO-Like Syndrome and Other Alterations in Mouse Ovaries. Int. J. Mol. Sci. 2021, 22, 5691. [CrossRef] [PubMed]

62. Lee, S.R.; Choi, W.-Y.; Heo, J.H.; Huh, J.; Kim, G.; Lee, K.-P.; Kwun, H.-J.; Shin, H.-J.; Baek, I.-J.; Hong, E.-J. Progesterone increases blood glucose via hepatic progesterone receptor membrane component 1 under limited or impaired action of insulin. Sci. Rep. 2020, 10, 1-11. [CrossRef] [PubMed]

63. Lin, T.-H.; Tan, T.-W.; Tsai, T.-H.; Chen, C.-C.; Hsieh, T.-F.; Lee, S.-S.; Liu, H.-H.; Chen, W.-C.; Tang, C.-H. D-pinitol Inhibits Prostate Cancer Metastasis through Inhibition of $\alpha \mathrm{V} \beta 3$ Integrin by Modulating FAK, c-Src and NF- $\mathrm{kB}$ Pathways. Int. J. Mol. Sci. 2013, 14, 9790-9802. [CrossRef] [PubMed]

64. Cooper, J.; Giancotti, F.G. Integrin Signaling in Cancer: Mechanotransduction, Stemness, Epithelial Plasticity, and Therapeutic Resistance. Cancer Cell 2019, 35, 347-367. [CrossRef]

65. Elangbam, C.S.; Qualls, C.W.; Dahlgren, R.R. Cell Adhesion Molecules-Update. Vet. Pathol. 1997, 34, 61-73. [CrossRef]

66. Ruiz-Ojeda, F.J.; Wang, J.; Bäcker, T.; Krueger, M.; Zamani, S.; Rosowski, S.; Gruber, T.; Onogi, Y.; Feuchtinger, A.; Schulz, T.J.; et al. Active integrins regulate white adipose tissue insulin sensitivity and brown fat thermogenesis. Mol. Metab. 2021, 45, 101147. [CrossRef]

67. Lessey, B.A.; Castelbaum, A.J.; Buck, C.A.; Lei, Y.; Yowell, C.W.; Sun, J. Further characterization of endometrial integrins during the menstrual cycle and in pregnancy. Fertil. Steril. 1994, 62, 497-506. [CrossRef]

68. Apparao, K.; Lovely, L.P.; Gui, Y.; Lininger, R.A.; Lessey, B.A. Elevated Endometrial Androgen Receptor Expression in Women with Polycystic Ovarian Syndrome1. Biol. Reprod. 2002, 66, 297-304. [CrossRef] [PubMed]

69. Bowen, J.A.; Bazer, F.W.; Burghardt, R. Spatial and Temporal Analyses of Integrin and Muc-1 Expression in Porcine Uterine Epithelium and Trophectoderm in Vivo1. Biol. Reprod. 1996, 55, 1098-1106. [CrossRef]

70. Kang, Y.-J.; Forbes, K.; Carver, J.; Aplin, J.D. The role of the osteopontin-integrin $\alpha v \beta 3$ interaction at implantation: Functional analysis using three different in vitro models. Hum. Reprod. 2014, 29, 739-749. [CrossRef] [PubMed]

71. Wang, S.; Zhou, X.; Yang, J. Integrin $\alpha v \beta 3$ Is Essential for Maintenance of Decidua Tissue Homeostasis and of Natural Killer Cell Immune Tolerance During Pregnancy. Reprod. Sci. 2018, 25, 1424-1430. [CrossRef]

72. Germeyer, A.; Savaris, R.F.; Jauckus, J.; Lessey, B. Endometrial beta3 Integrin profile reflects endometrial receptivity defects in women with unexplained recurrent pregnancy loss. Reprod. Biol. Endocrinol. 2014, 12, 1-5. [CrossRef]

73. Elnaggar, A.; Farag, A.H.; Gaber, M.E.; Hafeez, M.A.; Ali, M.S.; Atef, A.M. AlphaVBeta3 Integrin expression within uterine endometrium in unexplained infertility: A prospective cohort study. BMC Women's Health 2017, 17, 1-9. [CrossRef]

74. Lessey, B.A.; Castelbaum, A.J.; Sawin, S.W.; Buck, C.A.; Schinnar, R.; Bilker, W.; Strom, B.L. Aberrant integrin expression in the endometrium of women with endometriosis. J. Clin. Endocrinol. Metab. 1994, 79, 643-649. [CrossRef]

75. Kimmins, S.; Lim, H.C.; Parent, J.; Fortier, M.A.; MacLaren, L.A. The effects of estrogen and progesterone on prostaglandins and integrin beta 3 ( $\beta 3$ ) subunit expression in primary cultures of bovine endometrial cells. Domest. Anim. Endocrinol. 2003, 25, 141-154. [CrossRef]

76. Lessey, B.A. Two pathways of progesterone action in the human endometrium: Implications for implantation and contraception. Steroids 2003, 68, 809-815. [CrossRef] [PubMed]

77. Hills, F.A.; Abrahams, V.M.; González-Timón, B.; Francis, J.; Cloke, B.; Hinkson, L.; Rai, R.; Mor, G.; Regan, L.; Sullivan, M.; et al. Heparin prevents programmed cell death in human trophoblast. Mol. Hum. Reprod. 2006, 12, 237-243. [CrossRef]

78. Liu, H.; Radisky, D.C.; Yang, D.; Xu, R.; Radisky, E.; Bissell, M.J.; Bishop, J.M. MYC suppresses cancer metastasis by direct transcriptional silencing of $\alpha \mathrm{v}$ and $\beta 3$ integrin subunits. Nat. Cell Biol. 2012, 14, 567-574. [CrossRef] [PubMed]

79. Matsuda, S.; Fujita, T.; Kajiya, M.; Takeda, K.; Shiba, H.; Kawaguchi, H.; Kurihara, H. Brain-derived neurotrophic factor induces migration of endothelial cells through a TrkB-ERK-integrin $\alpha$ Vß3-FAK cascade. J. Cell. Physiol. 2012, 227, 2123-2129. [CrossRef]

80. Douma, S.; van Laar, T.; Zevenhoven, J.; Meuwissen, R.; Van Garderen, E.; Peeper, D.S. Suppression of anoikis and induction of metastasis by the neurotrophic receptor TrkB. Nat. Cell Biol. 2004, 430, 1034-1039. [CrossRef] [PubMed] 
81. Bao, W.; Qiu, H.; Yang, T.; Luo, X.; Zhang, H.; Wan, X. Upregulation of TrkB Promotes Epithelial-Mesenchymal Transition and Anoikis Resistance in Endometrial Carcinoma. PLoS ONE 2013, 8, e70616. [CrossRef]

82. Li, T.; Yu, Y.; Song, Y.; Li, X.; Lan, D.; Zhang, P.; Xiao, Y.; Xing, Y. Activation of BDNF/TrkB pathway promotes prostate cancer progression via induction of epithelial-mesenchymal transition and anoikis resistance. FASEB J. 2020, 34, 9087-9101. [CrossRef] [PubMed]

83. Miller, P.G.; Al-Shahrour, F.; Hartwell, K.A.; Chu, L.P.; Järås, M.; Puram, R.V.; Puissant, A.; Callahan, K.P.; Ashton, J.; McConkey, M.E.; et al. In Vivo RNAi Screening Identifies a Leukemia-Specific Dependence on Integrin Beta 3 Signaling. Cancer Cell 2013, 24, 45-58. [CrossRef]

84. Seguin, L.; Kato, S.; Franovic, A.; Camargo, M.F.; Lesperance, J.; Elliott, K.C.; Yebra, M.; Mielgo, A.; Lowy, A.M.; Husain, H.; et al. An integrin $\beta 3-K R A S-R a l B$ complex drives tumour stemness and resistance to EGFR inhibition. Nat. Cell Biol. 2014, 16, 457-468. [CrossRef] [PubMed]

85. Sethi, G.; Ahn, K.S.; Sung, B.; Aggarwal, B.B. Pinitol targets nuclear factor- $\kappa$ B activation pathway leading to inhibition of gene products associated with proliferation, apoptosis, invasion, and angiogenesis. Mol. Cancer Ther. 2008, 7, 1604-1614. [CrossRef]

86. Choi, M.-S.; Lee, W.-H.; Kwon, E.-Y.; Kang, M.A.; Lee, M.-K.; Park, Y.B.; Jeon, S.-M. Effects of Soy Pinitol on the Pro-Inflammatory Cytokines and Scavenger Receptors in Oxidized Low-Density Lipoprotein-Treated THP-1 Macrophages. J. Med. Food 2007, 10, 594-601. [CrossRef]

87. Lee, J.S.; Jung, I.D.; Jeong, Y.-I.; Lee, C.-M.; Shin, Y.K.; Lee, S.-Y.; Suh, D.-S.; Yoon, M.-S.; Lee, K.-S.; Choi, Y.H.; et al. d-pinitol inhibits Th1 polarization via the suppression of dendritic cells. Int. Immunopharmacol. 2007, 7, 791-804. [CrossRef] [PubMed]

88. Lee, J.S.; Lee, C.-M.; Jeong, Y.-I.; Jung, I.D.; Kim, B.-H.; Seong, E.-Y.; Kim, J.-I.; Choi, I.-W.; Chung, H.Y.; Park, Y.-M. d-pinitol regulates Th1/Th2 balance via suppressing Th2 immune response in ovalbumin-induced asthma. FEBS Lett. 2006, 581, 57-64. [CrossRef]

89. Fortis-Barrera, Á.; Aguilar, F.A.; Banderas-Dorantes, T.; Diaz-Flores, M.; Román-Ramos, R.; Cruz, M.; García-Macedo, R. C ucurbita ficifolia Bouché (Cucurbitaceae) and D-chiro-inositol modulate the redox state and inflammation in 3T3-L1 adipocytes. J. Pharm. Pharmacol. 2013, 65, 1563-1576. [CrossRef]

90. Kunjara, S.; Wang, D.Y.; McLean, P.; Greenbaum, A.; Rademacher, T.W. Inositol Phosphoglycans and the Regulation of the Secretion of Leptin: In Vitro Effects on Leptin Release from Adipocytes and the Relationship to Obesity. Mol. Genet. Metab. 2000, 70,61-68. [CrossRef]

91. Zhang, B.; Guo, X.; Li, Y.; Peng, Q.; Gao, J.; Liu, B.; Wang, M. d-Chiro inositol ameliorates endothelial dysfunction via inhibition of oxidative stress and mitochondrial fission. Mol. Nutr. Food Res. 2017, 61, 1600710. [CrossRef] [PubMed]

92. Kuroda, J.; Ago, T.; Matsushima, S.; Zhai, P.; Schneider, M.; Sadoshima, J. NADPH oxidase 4 (Nox4) is a major source of oxidative stress in the failing heart. Proc. Natl. Acad. Sci. USA 2010, 107, 15565-15570. [CrossRef] [PubMed]

93. Dodson, M.; De La Vega, M.R.; Cholanians, A.B.; Schmidlin, C.J.; Chapman, E.; Zhang, D.D. Modulating NRF2 in Disease: Timing Is Everything. Annu. Rev. Pharmacol. Toxicol. 2019, 59, 555-575. [CrossRef]

94. Ahmed, S.M.U.; Luo, L.; Namani, A.; Wang, X.J.; Tang, X. Nrf2 signaling pathway: Pivotal roles in inflammation. Biochim. Biophys. Acta Mol. Basis Dis. 2017, 1863, 585-597. [CrossRef]

95. You, H.J.; Oh, D.-K.; Ji, G.E. Anticancerogenic effect of a novel chiroinositol-containing polysaccharide fromBifidobacterium bifidumBGN4. FEMS Microbiol. Lett. 2004, 240, 131-136. [CrossRef]

96. Kim, Y.-S.; Park, J.-S.; Hwang, B.Y.; Lee, C.-K.; Song, S. Inhibitory Effect of D-chiro-inositol on Both Growth and Recurrence of Breast Tumor from MDA-MB-231 Cancer Cells. Nat. Prod. Sci. 2017, 23, 35-39. [CrossRef]

97. Rengarajan, T.; Nandakumar, N.; Rajendran, P.; Haribabu, L.; Nishigaki, I.; Balasubramanian, M.P. D-Pinitol Promotes Apoptosis in MCF-7 Cells via Induction of p53 and Bax and Inhibition of Bcl-2 and NF-kB. Asian Pac. J. Cancer Prev. 2014, 15, $1757-1762$. [CrossRef]

98. Rengarajan, T.; Nandakumar, N.; Rajendran, P.; Ganesh, M.K.; Balasubramanian, M.P.; Nishigaki, I. d-pinitol mitigates tumor growth by modulating interleukins and hormones and induces apoptosis in rat breast carcinogenesis through inhibition of NF- $\mathrm{kB}$. J. Physiol. Biochem. 2015, 71, 191-204. [CrossRef] [PubMed]

99. Yao, X.; Shi, K.; Yang, Y.; Gu, X.; Tan, W.; Wang, Q.; Gao, X.; Veeraraghavan, V.P.; Mohan, S.K.; Jin, S. D-Pinitol treatment induced the apoptosis in human leukemia MOLT-4 cells by improved apoptotic signaling pathway. Saudi J. Biol. Sci. 2020, 27, 2134-2138. [CrossRef] 